\title{
ANALISIS TINGKAT PEMAHAMAN KONSEP STATISTIKA MAHASISWA CALON GURU MENGGUNAKAN TWO TIER TEST BERBASIS ONLINE \\ ${ }^{1)}$ Sartika Arifin, ${ }^{2)}$ Aprisal \\ ${ }^{1,2)}$ Universitas Sulawesi Barat, Jalan Prof. Dr. Baharuddin Lopa, S. H., Baurung, Banggae \\ Timur, Majene, Sulawesi Barat \\ ${ }^{1)}$ sartikaarifin91@unsulbar.ac.id, ${ }^{2}$ aprisal@unsulbar.ac.id
}

\begin{abstract}
Received : $03 / 06 / 2020$

Accepted :

$13 / 07 / 2020$

Published :

29/07/2020

Abstract

Understanding concept is the basic of studying mathematics. Existing principles in mathematics can be applied if mathematical concepts can be understood properly. This study aims to analyze the level of understanding of mathematical concepts, especially statistics through the use of online-based two-tier test questions. The research subjects were English language students in semester IV with 75 respondents. The results of data analysis using the two tier test found that the level of understanding of students on the indicator of understanding by $35 \%$, misconception- 1 by $20.67 \%$, misconception- 2 by $15 \%$, and not understanding by $29.33 \%$. Other results show that students' understanding of the concept at the level of comparison is only $13.33 \%$ which is far lower than the other three indicators namely interpreting, classifying, and interferring.
\end{abstract}

Keywords: understanding concept, two tier test

\begin{abstract}
Abstrak
Pemahaman konsep merupakan hal dasar mempelajari matematika. Prinsip yang ada pada matematika dapat diterapkan jika konsep matematika dapat dipahami dengan baik. Penelitian ini bertujuan untuk menganalisis tingkat pemahaman konsep matematika khususnya statistika melalui penggunaan instrument soal two tier test berbasis online.. Subjek penelitian adalah mahasiswa pendidikan Bahasa Inggris semester IV dengan jumlah responden 75 mahasiswa. Hasil analisis data menggunakan two tier test diperoleh bahwa tingkat pemahaman mahasiswa pada indikator memahami sebesar 35\%, miskonsepsi-1 sebesar 20,67\%, miskonsepsi-2 sebesar 15\%, dan tidak memahami sebesar 29,33\%. Hasil lain menunjukkan bahwa pemahaman konsep mahasiswa pada level comparing hanya sebesar 13,33\% jauh lebih rendah dibandingkan dengan ketiga indikator lainnya yaitu interpreting, classifying, dan interferring.
\end{abstract}

Kata Kunci: pemahaman konsep, two tier test

\section{Pendahuluan}

Era revolusi industri 4.0 adalah era di mana kemajuan teknologi berkembang pesat. Hal ini tentunya berdampak pada seluruh aspek kehidupan tidak terkecuali pada aspek pendidikan. Berlakunya era revolusi industri 4.0, maka menuntut pendidik dan pembelajar mengikuti perkembangan zaman dengan memanfaatkan teknologi. Hal ini menjadikan guru mulai merubah paradigma proses pembelajaran yang berlangsung dari yang sepenuhnya tatap muka di kelas menjadi pembelajaran tatap muka-daring (blended learning).

Fenomena saat sekarang ini adalah adanya pandemi covid-19 yang menuntut setiap orang menerapkan social atau physical distancing. Aturan ini berdampak pada proses pembelajaran sehingga mendorong sekolah maupun perguruan tinggi untuk melaksanakan kegiatan pembelajaran di rumah. Setiap pendidik, guru, atau dosen dituntut mengadakan perkuliahan dari rumah atau work from home (WFH), sementara 
siswa/mahasiswa melakukan study from home (SFH). Kegiatan pembelajaran tersebut menjadi hal baru bagi kebanyakan guru maupun guru. Kegiatan pembelajaran yang semestinya berlangsung di kelas dialihkan pembelajaran secara online. Pembelajaran yang demikian menutut guru/dosen untuk lebih mempersiapkan pembelajaran lebih efektif dan efesien.

Pembelajaran yang efektif dan efesien dituntut karena adanya waktu yang membatasi setiap pertemuan pembelajaran, sehingga diharapkan guru dapat menyampaikan keseluruhan materi pembelajaran dalam waktu yang terbatas. Salah satu komponen penting yang mendukung pembelajaran adalah penggunaan software pembelajaran. Namun demikian, software pembelajaran yang digunakan belum mampu menyediakan waktu yang memadai bagi guru untuk menyampaikan materi kepada siswa. Pembelajaran ini sebenarnya dapat menjadi inovasi dalam dunia pendidikan khususnya proses belajar mengajar. Fakta lain di lapangan bahwa terdapat banyak keluhan dari guru dan siswa terkait proses pembelajaran yang berlangsung. Di kalangan guru kendala yang terjadi adalah guru kurang mampu menggukan software pembelajaran yang ada. Sementara bagi siswa adalah kendala dalam hal jaringan internet yang tidak tersedia secara memadai di beberapa wilayah. Kondisi tersebut menimbulkan pertanyaan di kalangan pemerhati pendidikan, apakah guru benar-benar melakukan bimbingan pembelajaran kepada siswa atau sekedar pemberian tugas. Di sisi lain pertanyaan lain adalah apakah siswa benar-benar memahami konsep materi yang diajarkan khsususnya pada mata pelajaran matematika. Oleh karena kondisi tersebut, pada penelitian akan dianalisis tingkat pemahaman konsep matematika khususnya statistika pada mahasiswa.

Salah satu goal mempelajari statistika di tingkat perguruan tinggi adalah mahasiswa mampu mengolah data, yang ini sangat bermanfaat bagi mahasiswa ke depannya di saat sudah berada pada tahap penyusunan skripsi. Oleh karena itu, dosen pengampu mata kuliah perlu mencapai tujuan pembelajaran dari statistika tersebut.

Agar tujuan pembelajaran tercapai maka diperlukan siklus umpan balik tentang sejauh mana keberhasilan pembelajaran sehingga perbaikan proses belajar mengajar berikutnya dapat terjadi secara optimal (Suwarto, 2010). Keberhasilan dalam pembelajaran ini adalah pemahaman konsep statistika mahasiswa.

Konsep dalam matematika didefinisikan sebagai ide abstrak yang digunakan untuk mengelompokkan objek yang termasuk contoh dan non-contoh. Penguasaan konsep pada pembelajaran matematika sangat penting karena sebagai dasar untuk meningkatkan kemampuan lain seperti kemampuan komunikasi, penalaran, koneksi, dan pemecahan masalah (Khamidah \& Warniasih, 2019). Cahyo (2013) mengungkapkan bahwa langkah awal bagi siswa agar dapat menyelesaikan soal-soal dan mengaplikasikannya dalam permasalahan sehari-hari adalah memahami konsep. Salah satu subjek matematika adalah statistika. Statistika merupakan materi bahkan menjadi salah satu mata kuliah yang dipelajari hampir semua mahasiswa di jurusan manapun.

Sementara itu, pemahaman adalah suatu proses yang terdiri dari kemampuan untuk menerangkan dan menginterpretasikan sesuatu, mampu memberikan gambaran, contoh, dan penjelasan yang lebih luas dan memadai, sedangkan konsep merupakan 
sesuatu yang tergambar dalam pikiran, suatu pemikiran, gagasan, atau suatu pengertian. Anderson \& Krathwohl (2010) mengemukakan bahwa dalam memahami suatu konsep terjadi setidaknya tujuh proses kognitif yakni 1) menafsirkan (interpreting), yaitu mengubah dari suatu bentuk informasi ke bentuk informasi lainnya, misalnya dari katakata ke grafik atau gambar, atau sebaliknya, dari kata-kata ke angka, atau sebaliknya, maupun dari kata-kata ke kata-kata, misalnya meringkas atau membuat paraphrase; 2) memberikan contoh (exemplifying), yaitu memberikan contoh dari suatu konsep atau prinsip yang bersifat umum. Memberikan contoh menuntut kemampuan mengidentifikasi ciri khas suatu konsep dan selanjutnya menggunakan ciri tersebut untuk membuat contoh; 3) mengklasifikasikan (classifying), yaitu mengenali bahwa sesuatu (benda atau fenomena) masuk dalam kategori tertentu; 4) meringkas (summarizing), yaitu membuat suatu pernyataan yang mewakili seluruh informasi atau membuat suatu abstrak dari sebuah tulisan; 5) menarik inferensi (inferring), yaitu menemukan suatu pola dari sederetan contoh atau fakta; 6) membandingkan (comparing), yaitu mendeteksi persamaan dan perbedaan yang dimiliki dua objek, ide ataupun situasi; 7) menjelaskan (explaining), yaitu mengkonstruk dan menggunakan model sebab-akibat dalam suatu sistem. Berdasarkan indikator-indikator tersebut peneliti menggunakan empat indikator yaitu menafsirkan (interpreting), mengklasifikasikan (classifying), menarik inferensi/menyimpulkan (inferring); serta membandingkan (comparing).

Widyatmoko (2018) mengemukakan bahwa untuk mengukur pemahaman konsep siswa jika jumlah sampel yang cukup besar dengan waktu yang singkat dibandingkan dengan wawancara yang memakan banyak waktu dapat digunakan tes pilihan ganda. Salah satu bentuk tes pilihan ganda adalah menggunakan two tier test. Two tier test merupakan tes yang berbentuk pilihan ganda yang terdiri dari dua tingkatan yakni tingkatan pertama dan tingkatan kedua. Tingkatan pertama adalah butir tes yang mengungkap suatu konsep tertentu dan tingkatan yang kedua adalah butir tes yang mengungkap alasan responden tentang jawaban yang diberikan pada butir tes yang pertama. Kanli (2015) menekankan kurang memadainya penggunaan tes pilihan ganda yang umum digunakan dalam menentukan pemahaman konsep dan tercapainya penggunaan multi tier test seperti two tier test. Salah satu kefektifan penggunaan two tier test berbasis online bahwa dapat mengetahui tingkat pemahaman seorang individu dibandingkan dengan tes lainnya karena terdiri dari dua timgkatan yakni jawaban dan alasan. Hal ini didukung oleh penelitian Nabilah (2013) yang menyatakan bahwa two tier test lebih efektif untuk menentukan tingkat pemahaman konsep siswa daripada menggunakan one tier test. Selain itu, pendapat Lin, Yang, \& Li (2016) mengatakan bahwa dengan two tier test dapat mengetahui tingkat pemahaman individu tanda menggunakan waktu yang banyak terbuang dan kertas yang banyak, serta diperlukan usaha keras untuk menganalisis data.

Evaluasi menggunakan two tier test dalam penelitian ini dilaksanakan dengan berbasis online yakni merancang soal menggunakan google form. Kelebihan two-tier test berbasis online adalah menghemat kertas, menggunakan waktu yang singkat, serta mengurangi tindakan mahasiswa yang asal memilih jawaban saja. Two-tier test juga memudahkan pendidik melakukan penskoran sehingga dalam menganalisis siswa yang 
mengalami kesulitan belajar semakin mudah dan cepat (Bayrak, 2013). Bentuk tes tersebut juga mampu mengukur tingkat pemahaman konsep yang dimiliki siswa baik siswa paham konsep, tidak paham konsep, atau siswa yang mengalami kesalahan pemahaman konsep. Oleh karena itu, tujuan dari penelitian ini adalah untuk mendeskripsikan tingkat pemahaman konsep mahasiswa calon guru pada mata kuliah Statistika menggunakan two tier test berbasis online.

\section{Metode Penelitian}

Penelitian ini merupakan penelitian deskriptif kuantitatif dan kualitatif yang menganalisis tentang tingkat pemahaman konsep statistika mahasiswa melalui penggunaan instrumen soal two tier test berbasis online. Pemahaman mahasiswa akan dianalisis secara kualitatif dengan menggunakan persentase pemahaman konsep siswa. Subjek penelitian ini adalah mahasiswa pendidikan Bahasa Inggris Universitas Sulawesi Barat semester IV angkatan 2018 yang terdiri 75 orang mahasiswa. Pemilihan subjek penelitian dilakukan dengan teknik purposive sampling.

Instrument penelitian yang digunakan adalah two tier test tersusun dalam bentuk google form. Instrument two tier test terdiri dari dua tingkatan tes yaitu first tier dan second tier. Tingkat pertama (first-tier) dari setiap item adalah pertanyaan pilihan ganda dengan empat pilihan jawaban (answer tier). Second tier dari setiap item berisi 4 alasan setiap pilihan (reason-tier). Tingkat pemahaman siswa ditentukan berdasarkan pola jawaban pada tingkat pertama dan tingkat kedua yang ditunjukkan pada Tabel 1.

Tabel 1. Tingkat Pemahaman Konsep dengan Two Tier Test

\begin{tabular}{cccc}
\hline $\begin{array}{c}\text { First Tier } \\
\text { (Jawaban) }\end{array}$ & $\begin{array}{c}\text { Second Tier } \\
\text { (Alasan) }\end{array}$ & Tingkatan & Deskripsi \\
\hline Benar & Benar & M & Memahami \\
Benar & Salah & MK-1 & Miskonsepsi-1 \\
Salah & Benar & MK-2 & Miskonsepsi-2 \\
Salah & Salah & TM & Tidak memahami \\
\hline
\end{tabular}

Kriteria penilaian pada two tier test adalah modifikasi dari Bayrak (2013) yakni mahasiswa mendapat skor 1 jika menjawab benar pada tingkat pertama dan mendapat skor 0 (nol) jika menjawab salah pada tingkat pertama (Nabilah, 2013). Pedoman penskoran pemahaman konsep statistika dapat dilihat pada Tabel 2.

Kemudian skor yang diperoleh dikonversi dalam skor 100 dengan rumus

$$
N=\frac{\text { skor perolehan }}{\text { skor total }} \times 100
$$

Keterangan: $\mathrm{N}$ adalah skor pemahaman konsep statistika (Arifin, 2020)

Prosedur perancangan penelitian ini memiliki tiga langkah utama yang akan dilakukan, yaitu prosedur persiapan penyusunan instrumen penelitian dengan google form, prosedur pengumpulan data, dan prosedur pengolahan data hasil penelitian. 
Tabel 2. Pedoman Skor Pemahaman Konsep Statistika Mahasiswa Calon Guru

\begin{tabular}{|c|c|c|}
\hline Indikator pemahaman konsep & Kriteria & Skor \\
\hline \multirow{4}{*}{ Interpreting } & - $\quad$ Menjawab benar dan alasan benar & 1 \\
\hline & - Menjawab benar dan alasan salah & 1 \\
\hline & - Menjawab salah dan alasan benar & 0 \\
\hline & - Menjawab salah dan alasan salah & 0 \\
\hline \multirow{4}{*}{ Classifying } & - Menjawab benar dan alasan benar & 1 \\
\hline & - Menjawab benar dan alasan salah & 1 \\
\hline & - Menjawab salah dan alasan benar & 0 \\
\hline & - Menjawab salah dan alasan salah & 0 \\
\hline \multirow{4}{*}{ Interferring } & - Menjawab benar dan alasan benar & 1 \\
\hline & - Menjawab benar dan alasan salah & 1 \\
\hline & - Menjawab salah dan alasan benar & 0 \\
\hline & - Menjawab salah dan alasan salah & 0 \\
\hline \multirow{4}{*}{ Comparing } & - $\quad$ Menjawab benar dan alasan benar & 1 \\
\hline & - Menjawab benar dan alasan salah & 1 \\
\hline & - Menjawab salah dan alasan benar & 0 \\
\hline & _ Menjawab salah dan alasan salah & 0 \\
\hline
\end{tabular}

\section{Hasil dan Pembahasan}

Penelitian ini dilakukan di Prodi Pendidikan Bahasa Inggris Universitas Sulawesi Barat. Data yang diperoleh menggunakan two tier test diberikan kepada mahasiswa. Pelaksanaan two tier test menggunakan google form mencakup dua bagian yakni jawaban dan alasan. Setelah mahasiswa menentukan jawaban pada setiap soal (first tier) maka mereka diperkenankan untuk memilih alasannya juga atau second tier. Berikut gambaran umum tingkat pemahaman konsep statistika mahasiswa calon guru.

Tabel 3. Persentase Rata-Rata Tingkat Pemahaman Statistika Mahasiswa dengan Two Tier Test

\begin{tabular}{cccccc}
\hline $\begin{array}{c}\text { Indikator Tingkat } \\
\text { Pemahaman }\end{array}$ & $\begin{array}{c}\text { Interpreting } \\
(\%)\end{array}$ & Classifying (\%) & $\begin{array}{c}\text { Interferring } \\
(\%)\end{array}$ & $\begin{array}{c}\text { Comparring } \\
(\%)\end{array}$ & $\begin{array}{c}\text { Rata- } \\
\text { rata (\%) }\end{array}$ \\
\hline M & 70,67 & 30,67 & 29,33 & 9,33 & 35 \\
MK1 & 24 & 38,67 & 16 & 4 & 20,67 \\
MK2 & 1,33 & 10,67 & 17,33 & 30,67 & 15 \\
TM & 4 & 20 & 37,33 & 56 & 29,33 \\
\hline
\end{tabular}

Pada Tabel 3 diperoleh bahwa, kategori memahami (M) memiliki rata-rata skor yang paling besar di antara kategori lainnya, yaitu sebesar 35\%. Pada kategori memahami, indikator interpreting mempunyai rata-rata perolehan skor tertinggi, yaitu sebesar 70,67\%. Namun demikian, diperoleh fakta bahwa mahasiswa lemah dalam membandingkan satu konsep dengan konsep lainnya. Pada kategori miskonsepsi-1 (MK1) diperoleh rata-rata kemampuan tingkat pemahaman konsep mahasiswa adalah sebesar 20,67\%. Pada kategori ini diperoleh fakta bahwa mahasiswa unggul dalam mengklasifikasikan konsep, tetapi lemah dalam membandingkan konsep yang berbeda. Hal lain yang menarik bahwa, pada kategori miskonsepsi-2 (MK2) dan kategori tidak memahami (TM) mahasiswa dapat dengan baik membandingkan jika dihadapkan dua konsep yang berbeda, tetapi kurang pemahaman jika menafsirkan soal, sehingga akan mempengaruhi konsep yang digunakan dalam menyelesaikan soal statistika. 
Hasil survei pekerjaan mahasiswa, yaitu mahasiswa pada kategori TM, mereka salah menafsirkan maksud dari soal atau dengan kata lain sulit menganalisis soal sehingga memilih jawaban yang salah. Alasan lain bahwa mahasiswa pada kategori ini juga melakukan kesalahan perhitungan. Sementara mahasiswa pada kategori MK1 salah perhitungan dalam proses mendapatkan hasil. Hal ini dikarenakan karena masih ada mahasiswa yang menghitung secara manual atau tidak menggunakan software yang tersedia. Sementara itu, mahasiswa yang menggunakan software melakukan kesalahan penginputan data sehingga memperoleh output yang salah. Sedangkan pada mahasiswa kategori MK2 sulit dalam menganalisis maksud soal sehingga memilih jawaban yang salah, dan memilih jawaban yang benar itu hanya kebetulan.

Selanjutnya hasil skor pemahaman konsep mahasiswa setelah dikonversi ke angka 100, Akumulasi persentase rata-rata mahasiswa setiap indikator yakni pada tabel 4.

Tabel 4. Presentase Rata-Rata Pemahaman Konsep Mahasiswa

\begin{tabular}{llc}
\hline No & Indikator Pemahaman Konsep & Skor \\
\hline 1 & Interpreting & $94,67 \%$ \\
2 & Classifying & $69,33 \%$ \\
3 & Inferring & $42,67 \%$ \\
4 & Comparing & $13,33 \%$ \\
\hline
\end{tabular}

Berdasarkan Tabel 4 dapat dilihat bahwa lebih dari 50\% pada indikator interpreting dan classifying mahasiswa menjawab benar. Hal tersebut menunjukkan bahwa mahasiswa telah mampu menafsirkan dan mengklasifikasi konsep dengan benar. Hal ini didukung oleh penelitian Syarifah (2017) bahwa pemahaman konsep matematis mahasiswa yang paling tinggi adalah pada indikator kemampuan mengklasifikasikan objek-objek atau konsep-konsep menurut sifatnya. Sementara itu pada indikator inferring dan comparing, terdapat kurang dari 50\% mahasiswa menjawab salah. Jika ditelusuri lebih mendalam, faktor penyebab siswa gagal berada level yang lebih tinggi tentang pemahaman konsep matematika adalah siswa tidak memahami apa yang mereka pelajari. Kondisi akan berdampak pada siswa tidak mampu menyelesaikan soal yang lebih sulit seperti soal yang menuntut siswa untuk menyimpulkan bahkan soal pada tingkatan membandingkan. Hal ini didukung oleh pendapat Radfor (2013) bahwa kita tidak akan mengerti apa yang dipelajari jika tidak memahami dengan baik tentang apa yang dipelajari.

Berdasarkan Tabel 4 di atas, pada indikator comparing hanya mencapai 13,33\% yang menjawab benar. Artinya ada 65 dari 75 mahasiswa yang menjawab pada first tier dan second tier dengan pilihan yang salah. Soal yang disajikan pada indikator comparing adalah mengenai pengujian hipotesis. Mahasiswa yang menjawab salah disebabkan karena mereka masih bingung untuk mengambil keputusan apakah menerima atau menolak hipotesis null, sehingga berbagai macam cara mereka menjawab misalnya hanya menduga-duga pilihan jawaban dan alasannya. Bukan hanya karena kebingungan ada juga yang menjawab karena lupa dengan materi yang sudah dipelajari, sehingga asal pilih jawaban. Hal ini didukung dengan hasil pengerjaan dalam bentuk file yang dikirim masih kosong. 
Secara kognitif, salah satu penyebab siswa kurang dalam pemahaman konsep adalah karena terjadinya miskonsepsi pemahaman siswa. Miskonsepsi terjadi karena reasoning atau penalaran mahasiswa yang tidak lengkap atau salah sehingga konsep dasar tidak dipahami dengan baik oleh mahasiswa. Karena mahasiswa tidak memahami konsep dengan baik, maka aktivitas penalaran mereka tidak bisa digunakan dengan baik untuk menyelesaikan soal pada level tinggi. Hal ini sejalan dengan Aprisal \& Abadi (2018) bahwa penalaran adalah kegiatan pada proses berpikir tingkat tinggi yang tidak hanya menjawab apa yang ditanyakan, tetapi juga menjawab pertanyaan mengapa dan akhirnya sampai pada suatu kesimpulan. Selain itu aspek afektif juga mempengaruhi tinggi rendahnya tingkat pemahaman konsep mahasiswa. Salah satunya adalah kurangnya minat dalam belajar. Menurut Suparno (2005), mereka yang tidak berminat cenderung tidak mendengarkan dan memperhatikan secara penuh apa yang diajarkan oleh guru, sehingga konsep tersebut tidak dipahami secara menyeluruh.

Inilah salah satu kefektifan penggunaan two tier test berbasis online bahwa dapat mengetahui tingkat pemahaman seorang individu dibandingkan dengan tes lainnya karena terdiri dari dua tingkatan yakni jawaban dan alasan. Hal ini didukung oleh penelitian Nabilah (2013) yang menyatakan bahwa two tier test lebih efektif untuk menentukan tingkat pemahaman konsep siswa daripada menggunakan one tier test. Selain itu, pendapat Lin, Yang, \& Li (2016) mengatakan bahwa dengan two tier test dapat mengetahui tingkat pemahaman individu tanda menggunakan waktu yang banyak terbuang dan kertas yang banyak, serta diperlukan usaha keras untuk menganalisis data.

\section{Kesimpulan}

Berdasarkan hasil penelitian dan pembahasan, maka dapat disimpulkan bahwa analisis menggunakan instrument two tier test menghasilkan tingkat pemahaman konsep tiap mahasiswa diantaranya memahami (35\%), miskonsepsi-1 (20,67), miskonsepsi-2 (15\%), dan tidak memahami $(29,33 \%)$. Skor pemahaman konsep mahasiswa calon guru masih kurang dalam indikator comparring yang hanya memperoleh 13,33\% jauh lebih rendah dibandingkan dengan ketiga indikator lainnya yaitu interpreting, classifying, dan interpeting. Adapun saran yakni diharapkan agar meningkatkan dalam mengembangkan instrumen soal dengan jenis two tier karena salah satu alat yang dapat digunakan untuk mengetahui letak kesulitan belajar pembelajar.

\section{Pustaka}

Anderson, L., \& Krathwohl, D. (2010). Kerangka landasan untuk pembelajaran, pengajaran, dan assesmen. Yogyakarta: Pustaka Belajar.

Aprisal, A., \& Abadi, A. M. (2018). Improving students' mathematical reasoning and self-efficacy through missouri mathematics project and problem solving. Beta: Jurnal Tadris Matematika, 11(2) 2018, 191-208.

Arifin, S \& Aprisal, A. (2020). Penerapan model pembelajaran kooperatif tipe pair checks terhadap pemecahan masalah matematika. Jurnal Pendidikan Matematika, 11(1), 89-98. 
Bayrak, B. K. (2013). Using two-tier test to identify primary students' conceptual understanding and alternative conceptions in acid base. Mevlana International Journal of Education (MIJE). 3 (2). 19 -26.

Cahyo, A. (2013). Panduan aplikasi teori-teori belajar mengajar. Jakarta: PT. Diva Press.

Lin, Y. C., Yang, D. C., \& Li, M. N. (2016). Diagnosing students' misconceptions in number sense via a web two tier test. Eurasia Journal of Mathematics, Science \& Technology Education, 12(1), 41-55.

Khamidah \& Warniasih, K. (2019). Efektivitas model discovery learning ditinjau dari pemahaman konsep matematis siswa kelas XI IPS SMA Negeri 1 Gamping. Delta: Jurnal Ilmiah Pendidikan Matematika. 7 (1), 27-36.

Kanli, U. (2015). Using a two-tier test to analyse students' and teachers' alternative concepts in astronomy. Science Education International, 26(2), 148-165.

Nabilah, N., Andayani, Y., \& Laksmiwati, D. (2013). Analisis tingkat pemahaman konsep siswa kelas xi ipa sman 3 mataram menggunakan one tier dan two tier test materi kelarutan dan hasil kali kelarutan. J. PIJAR MIPA. VIII (2), 64-69.

Radfor, L. (2013). three key concepts of the theory of objectification: Knowledge, knowing, and learning. REDIMATH-Journal of Research in Mathematics Education, 2, 7-44.

Suparno, P. (2005). Miskonsepsi dan perubahan konsep dalam pendidikan fisika. Jakarta: PT. Grasindo.

Suwarto. (2010). Pengembangan The Two-Tier Diagnostic Tests Pada Bidang Biologi Secara Terkomputerisasi. Jurnal Penelitian dan Evaluasi Pendidikan, Tahun 12, Nomor 1, $206-224$.

Syarifah, L., L. (2017). Analisis kemampuan pemahaman matematis pada mata kuliah pembelajaran matematika SMA II. JPPM. 10 (2), 57-71.

Widiyatmoko, K dan Shimizu, K. (2018). The development of two-tier multiple choice test to assess students' conceptual understanding about light and optical instruments. Jurnal Pendidikan IPA Indonesia, 7(4), 491 - 501. 